\title{
PRECONDITIONS OF AN INTERCULTURAL DIALOGUE ON HUMAN RIGHTS
}

Marek Hrubec*

\begin{abstract}
The article deals with the issue of human rights regarding the potential for consensus among cultures by means of an intercultural dialogue. It is a contribution towards overcoming the confrontations among civilizations and to the eradication of the coercive imposing of human rights onto other cultures. The paper demonstrates that the intercultural promotion of human rights across individual cultures that recognize each other is one of the effective forms of resistance against people being misrecognized. However, this requires a formulation of human rights based on the values of individual cultures and the dialogue among them. The interpretation of the paper is a contribution to creating 'unity in plurality', i.e. a universality of human rights within the plurality of cultures.
\end{abstract}

KEYWORDS - Cultures. Intercultural dialogue. Human rights.

RESUMO - O artigo trata da questão dos direitos humanos quanto ao potencial de consenso entre culturas através do diálogo intercultural. Trata-se de uma contribuição para superar os confrontos entre civilizações e a imposição coercitiva de direitos humanos sobre outras culturas. O paper mostra que a promoção intercultural de direitos humanos entre culturas individuais que se reconhecem mutuamente é uma das formas efetivas de resistência contra a falta de reconhecimento. Todavia, é mister uma formulação dos direitos humanos embasada nos valores de culturas individuais e no diálogo entre elas. A interpretação aqui adotada é uma contribuição para criar 'unidade na pluralidade', i.e. uma universalidade de direitos humanos dentro da pluralidade de culturas.

PALAVRAS-CHAVE - Culturas. Diálogo intercultural. Direitos humanos

Different cultures interpret human rights in different ways. Therefore, it is not at all surprising that we are confronted with clashes among cultures. In this article, I will concentrate on the issue of human rights

* Professor, Charles University, Prague; Academy of Sciences of the Czech Republic.

\begin{tabular}{|l|l|l|l|l|l|}
\hline Veritas & Porto Alegre & v. 55 & n. 1 & jan./abr. 2010 & p. 183-205 \\
\hline
\end{tabular}


regarding the potential for consensus among cultures by means of an intercultural dialogue. The article may be considered as a contribution towards overcoming the confrontations among civilizations and to the eradication of the coercive imposing of human rights onto other cultures.

I would like to demonstrate that the intercultural promotion of human rights across individual cultures is one of the effective forms of resistance against people being misrecognized. However, this requires a formulation of human rights based on the values of individual cultures and the dialogue among them. In the first part of the article, I will briefly discuss the topic of conflict and dialogue; in the second part, I will focus in a hermeneutic way on the intercultural and inter-civilization nature of this conflict; in the third part, I will concentrate on human rights per se, and in the final part, I will touch on the legislation concerning human rights.

Such an interpretation which is a contribution to creating "unity in plurality' is not entirely a matter of course. The attention of most people is focused either purely on intercultural dialogue and the issues of cultural plurality or only on human rights and the issues of the universality of civilization of all human beings. The attempt to create a connection between both types of discourse may be interpreted as a part of an eradication of the frequent ideological misuse of human rights which deforms the intercultural dialogue and commonly shared human rights together with the conditions for their realization.

\section{Conflict and dialogue}

There are frequent intercultural conflicts in the present global climate which is characteristic of an increasing number of interactions of people from different cultures from the fields of economy, communication or other types of cultural interaction. This does not always mean a state of war. Conflicts take on diverse forms from the cultivated to aggressive ones (Arnason 2003). Although the confrontation of cultures and civilizations leads towards the polarization and culmination of the conflict, the intercultural dialogue among cultures attempts to contribute to their mutual recognition. ${ }^{1}$

These forms of conflict resolution did not develop as separate thought entities but stem from the development of mutual conflict relationships between people and the requirements for their resolution. The process of misrecognition of certain groups of populations in the long term historical

1 On the value of the role of dialogue, in other words, communication in relation to recognition see: Taylor (1992); Fraser, Honneth (2003). 
perspective causes their justified dissatisfaction and articulation of their claims for recognition. At the same time some types of misrecognition might be initiated by artificial conflicts which are invoked for the purpose of the legitimization of particular power structures or for the purpose of unjust economic and other interests. Despite the fact that some confrontations between cultures are fictional because they are forced upon people without any essential connection with the reality, a possibility of 'self-fulfilling prophecy' has at least a partial influence on the transformation of these conflicts into serious and real confrontations. The example may be the conflict between the West and Islam. The relationships between people are then formed as a complex of real and fictitious conflicts.

People react critically to the disadvantages and other forms of oppression which they face and in this way they map the individual problems that need to be resolved. In the background of their experienced reality they notice positive fragments of reality and try to develop them. In a relatively favorable environment, the criticism of current forms of misrecognition and attempts to correct them may be realized in the form of a cultivated intercultural dialogue. The notion of conflict then includes the notion of consensus which may assist the direction towards the desired final state.

The intercultural dialogue attempts to identify the current social norms through critical discussion and create new ones that might be shared by individual cultures in a universal way. Because the communication does not concern only two cultures and therefore a dia-logue in the literal sense, it is more precise to talk of a poly-logue. ${ }^{2}$ Such a broad concept of the discourse cannot in the least supplement the solutions to all the social, economic, political and other related problems. What can be done is nevertheless to provide conditions for an important intercultural framework for working on these problems.

The discourse which is the subject of my analysis contains two fundamental elements. The first one relates to the forming of a dialogue 'from below' from the perspective of various cultures and their relationship within human civilization. The second element is in the form of universal human rights which may be the outcome of this type of dialogue. This kind of approach, which is gradually formulated and subjected to many comments from individual cultures, could be the unifying and universal element (AN-NA'IM, 2002). In short, the objective is to reach a commonly

2 See The Forum for Intercultural Philosophy Polylog that holds a scientific discussion across nations and cultures http://polylog.org and also the polylog magazine Zeitschrift für interkulturelles Philosophieren. 
shared 'transcultural' consensus through intercultural means in order to replace the current supra-cultural situation which is not universally accepted.

\section{Culture and civilization}

What does it mean to talk about the dialogue which is supposed to be intercultural? The adjective may be initially read as an umbrella term which covers the relationships among individual cultures or civilizations or culture/civilization circles. This definition raises the question about the relationship between the words culture and civilization. The preliminary answer might be to define them as synonyms but under the condition that the limits and any possible misunderstandings are clarified before using these terms. Their frequent inter-changing is not only the case in the Western languages. For example there is also the Arabic word umran, which has a prominent place already in the teaching of Ibn Khaldun from the $14^{\text {th }}$ century, which can be translated either as civilization or as culture.

Some authors prefer to use the word civilization rather than the synonym approach. Yasuaki Onuma presents this term as more appropriate because the word culture may be interpreted also in a restricted sense in which it speaks only about art works and works with an aesthetic function (ONUMA, 1999). This is certainly correct. Moreover, aside this interpretation, another use of the word culture exists which is bound only by one type of human rights which are the cultural rights. Also in this case the word cultural is conceived in a limited sense which is concerned with the broader issue of the intercultural conflict about human rights, including the cultural rights (KROEBER and KLUCKHOHN, 1963).

The word civilization is likewise not used in one sense only. On the one hand it is designated to the whole human civilization in the entire humanity while on the other hand it is designated to just one of the civilizational or cultural circles; it is used for example in relation to the civilization or culture of the West, Islam or the Confucian world (BENJAMIN, 1973).

The first mentioned meaning of the word civilization has its origin in defining a specific stage of development of society or culture (DIAMOND, 1997). Civilization is trying to overcome the primitive stage of cultural development. It begins to essentially defer from a primitive culture at the moment when it becomes characterized by the complex organization of its society. Whereas primitive societies seem to be relatively static, civilizations are characterized by the process of development. It is possible to speak in detail about the gradual development from hordes 
to tribes and chiefdom to state and super-state formations. The criteria of differentiating between these types of cultures has taken into account population density, patterns of colonization, relationships between relatives or relationships within the society, the intensification of food production, the introduction of the division of labor and egalitarian or centralized types of decision making, informal or legal conflict management and so on. The trajectory of development had previously only its regional character, and its various historical stages were analyzed in far more detail than the complex planetary trajectory. Once the civilization stage of development of the majority of cultures spread on the planet, the discussion was concerned with one civilization of the whole humankind. Therefore, from the point of view of this explanation, the development proceeds from cultures to civilization. This process also allows the discussion about progress or regress. ${ }^{3}$

This interpretation is also compatible with the relating of civilization to the practical-technical sides of a society although the term 'culture' is then used in the opposite sense, that is not as more primitive but more developed product of a society. The distinction between culture and civilization is based on defining civilization by the technical dimensions of the society such as script, urbanism and so on. Culture is then ascribed, sometimes not without difficulties, to the more refined role related to values and humanistic ideals (TÖNNIES, 2005).

The disadvantage of this way of defining the word civilization, as used with regards to individual participating civilizations (Western, Islamic, Confucian and so on) is that it does not allow for discussion about inter-civilizational dialogue with cultures that did not reach the civilization stage of development. Dialogue is then reduced only to the discussion amongst technically developed civilizations and other cultures are left in power dependence on them or in other kind of dependence relationship.

Moreover the use of only one word civilization in the plural as well as the singular sense has a tendency to contentiously erase the difference between the cultural (plural) and the cosmopolitan (singular) meanings. These multiple meanings have their consequences for intercultural and transcultural discussion. The use of the word civilization in the plural sense may implicitly cling towards a discussion which omits the acknowledgment of differences of individual cultures and which aims towards a unifying approach. This approach then defines cultures with an emphasis on one civilization of the whole of humanity only. This

3 See, for example, Adorno, Horkheimer (1988; $1^{\text {st }}$ ed. Publ. in 1944). Compare with the alternative interpretation: Toynbee (1934-1961). 
kind of approach is usually not an embodiment of a true universalism which in the intercultural dialogue of a desirable and non-imposing manner tries to unify the current positive elements of individual cultures while also suggesting universally acceptable elements which could be voluntarily shared between individual cultures. It is more often the case of an imperialist point of view, whether reflected or not, which under the heading of civilization promotes one culture over another. The history of colonialism and the forms of colonialism which were legitimized by European universalism or more preciously by pseudo-universalism are its unfortunate consequences (WALLERSTEIN, 2006). The metatheoretical viewpoints commit the same transgression which without the contribution of other cultures and from the viewpoint of one culture, attempt to dictate which social concepts, values and so on, are relevant and eventually should be considered as universal. All these approaches are usually defined as a cultural imperialism (SAID, 1994; KÖGLER, 2005).

One way of preventing these kinds of problems is firstly to retain the wider sense of the term civilization, that is to use it only in the singular sense for defining the whole of human civilization and secondly to define the term culture by its plural connection with individual societies. The word culture might be seducing to various partial conceptions as I already mentioned, from culture as a collection of art works, to cultural aspects of various areas, for example cultural rights, to cultures which have not developed into complex civilizations and which have not the use of technology and also to cultures as a synonym of civilizations. Despite this wider notion, it is always various partial entities and not culture as a singular whole which is under consideration because culture is not usually thought of as an all-human culture but rather as various cultures or cultural plurality. Here we might refer to Majid Tehranian who, in his analysis of civilization and resolving of its conflicts, says that it is more adequate to analyze one human civilization and many human cultures (TEHRANIAN, 2007).

At the same time we should reject fixating purely on one of these categories, on civilization in a singular sense or on culture in plural sense. It is necessary to acknowledge both, the differences of individual cultures as well as the common values which bring humanity as a whole into one civilization. ${ }^{4}$ The key is that in this definition it is possible to respect plurality of opinions and to work 'from below' of individual cultures and

4 In the similar types of discussions within the framework of the national state, it is usual to differentiate between the politics of recognition or of difference and the politics of universalism or of equality. See Taylor (1994). 
aim towards their interconnectedness in one civilization. It seems to be appropriate from this viewpoint to reserve the plural meaning for the word culture and the singular meaning for the word civilization. At the same time there is a continuous exchange between the social constructions of these terms. Moreover, I would like to add that the concepts of culture and civilization, which are defined in the opposite sense than I presented here, may also reach a reasonable content of interpretation. ${ }^{5}$ The key is to define positions with the aid of terms and not by fixating on these terms.

One of the previously mentioned problems, which arises in connection with cultural imperialism, is the cultural particularism. Regarding its content it often promotes the same values as cultural imperialism but in its opposition it openly advocates its specifically non-universal viewpoint. Due to the fact that the advocates of cultural particularism emphasize essential differences of individual cultures, they frequently tend towards the opinion that individual cultures cannot reach commonly shared values and therefore they cannot in certain respects unify in one civilization and the community of human beings. The absence of the potential universal consensus predetermines this viewpoint, together with the cultural imperialism, to the confrontation of cultures. In this respect the word culture as well as the world civilization has the negative connotations because they both can refer to Kulturkampf or the Clash of Civilizations. ${ }^{6}$

While placing an emphasis on insurmountable differences between individual cultures, the advocates of cultural imperialism and cultural particularism frequently perceive cultures in a segregate way, as historically enclosed units and unchangeable given entities. Individual cultures are here conceived as specific essences (WALLERSTEIN, 2006). However, the essentialist view is disturbed by efforts to construct not only random elements of intercultural consensus based on the current partial overlapping of various cultural values, but also by elements of such a transcultural consensus which requires openness of individual cultures towards partial re-definition of their values. The intercultural dialogue does not accept the essentialist view. The essentialist view is confronted by the critique of generalization of cultures and the emphasis on the gradual formation of cultural patterns as social constructs which means the rejection of the transcultural essentialist view (SAMSON, SMITH, 1996).

5 It is possible to say that this is, to a large extent, a matter of terminology polemic and not of content polemics. See, for example, Onuma (1999).

6 Authors who develop these thoughts use these words often as synonyms. See, for example, Huntington (1996). Compare with an alternative interpretation: Senghaas (2007). 
Rejection of the essentialist view should not on the other hand lead towards the relativist view which is at the same time a resignation concerning the non-contingent transcultural consensus.

The conception of cultures in the intercultural and transcultural dialogue also requires a more exact identification of the cultural subjects of the dialogue. In relation to Lawrence Blum, the three categories can be distinguished, although none of which have to be designated definitely and can transform in time (BLUM, 1998; INGRAM, 1998). Firstly, it is possible to speak of an individual who is formed by a particular culture or an individual with a particular cultural identity (identities). Secondly, we may discuss a group of individuals specified by particular culture or group with particular cultural identity. Thirdly, we can analyze an entire culture.

The first category of the subject is not in the centre of attention in the intercultural dialogue because the dialogue primarily follows relationships between larger cultural units than individuals. The relationships at the individual level are certainly also important though, in the conflict of entire cultures, millions of individual persons do not enter into discussion but rather the representatives of people who can promote their individual and group interests. Nevertheless, it is important to make sure that the representatives of individual cultures do not represent just their own view and their own culture only marginally. But also in the case when the representatives are successful in representing their culture, they should not represent the mainstream of their culture more predominantly; it is obviously desirable to acknowledge the minority streams as well. This opens the question of a multi-cultural dialogue within the intracultural framework between the majority and minorities, between men and women, and so on (TAYLOR, 1994; SENGHAAS, 1998). Intra-cultural conflicts also largely relate to social conflicts. As mentioned by Yash Ghai in the context of East-Asian economies, a particular territory does not offer just one access to rights but the heads of companies stress other laws than unionists, and minorities emphasize other laws than the members of the majority, etc. (GHAI, 1999). Within the framework of intercultural dialogue, it is important to remember these significant socio-economic factors.

The other category which is formed by culturally formed groups of individuals includes in a more restricted sense the majority of the population of France, for example, and in the broader sense, the majority of the entire Western population. It is the population of the European Union, USA and other countries which have similarly specified cultural, economic and political systems, such as Canada, Australia and so on. A similar type of discussion could be initiated in relation to Islamic 
minorities in France and in the European Union in general. Although this is not a general rule, these minorities are often culturally related to the majority of another country: the Turkish minority in Germany is culturally related to the majority in Turkey, for example. Minorities and majorities of course cannot be considered as fixed and the ratio between the minority and the majority may significantly transform in time or even reverse its course.

The third category, which is formed by entire cultures or civilizations, if I use this term imprecisely, includes the creations of culturally defined groups, from art works to various social customs and finally to the whole life in the society, which is a collection of various social, political, legal and other entities. In the wider context and from the long-term perspective, it is also possible to add population to these creations which may be considered as a cultural product of itself. Population as it stands does not perceive itself as an object but asserts itself primarily as a creating subject which gradually forms cultural customs, rules and objects in interaction with the related environment.

What would it mean to refer to the third category in an intercultural dialogue which means the entire cultures? Charles Taylor speaks of the entire cultures when he expresses the need to recognize a cultural value of cultures which is required not only for a dialogue but in particular for their own life. He says that we should analyze and recognize the equal value of cultures (TAYLOR, 1994). In Taylor's interpretation, the recognition of equal respect to different cultures is analogous to the recognition of the equal dignity of individuals.

The question remains whether or not it is appropriate to apply an equal approach to individuals, which we implement in relation to their common characteristics, humanity or citizenship, for example, also for the recognition of cultures (BLUM, 1998). This approach to cultures seems problematic for two reasons. The first is the gnoseological argument about the difficulties in measuring the value of individual cultures. In order to evaluate the Afro-American culture or the Roma culture, for example, it would mean to consider them as some kind of totality to which we attribute a specific measurable value. The second argument relates to the difficulty in comparing the value of individual cultures even if this value was measurable. This does not mean the tendency towards relativism but only the acknowledgement of the problems of comparing entire cultures. The claim for value stems from justified and historically founded fears of dismissive Euro-centric or today more of a West-centric approach towards other cultures. One of the sources of this problematic approach is based on the thorough evaluative comparison of cultures which often led to the conclusion that the Euro-American culture is superior to other cultures. 
If we abandon these kinds of rigorous cultural comparisons and try to redefine Taylor's formulation by focusing primarily on the equal recognition of groups of people which are defined by a particular culture, there is a chance that we also rid ourselves of the dismissive West-centric attitude. Then, it will be possible to better understand the requirements of the politics of recognition. It is also necessary not to slip towards an interpretation which homogeneously ignores various groups of individuals with diverse cultural identity, or to the approach which uses exact techniques of measurement and subsequently sorts them into hierarchic categories.

These kinds of arguments lead back to the second category of the subject, i.e. to groups of individuals, whether they are small communities in the position of a minority or larger communities in the form of a majority or even entire 'cultures', although here it is cultures in the sense of groups of individuals and not cultural entities which are not defined by human subjects.

Groups of individuals may at the same time have two basic requirements which are often connected with legal requirements: one is the claim for their recognition as subjects with different cultural identity which will not be ignored, and the second requirement is the claim that these groups as subjects of a dialogue and action are recognized by others as equal to other groups. Although this kind of conception of subjects of intercultural dialogue is not entirely ideal and requires a certain amount of reformulation which is not necessary for the purpose of this text, nevertheless, this approach is more suitable than the approach which talks about entire cultures or civilizations without a recognition of the groups of individuals. In the contemporary global age when national states losing their dominant position, to adopt a politics towards culturally defined groups of individuals is a politics which is generally more farsighted than the current obsolete stance of international law which is almost entirely fixated on national states. ${ }^{7}$

\section{Human Rights}

In continuity with the explanation I offered above, it is possible to say that the connecting element between the cultures, which are primarily

7 It is important to add that recognition should aim not only towards contemporary components of groups of individuals but also towards the entire historical experience of these groups. For example, to recognize only the present components of the group of Afro-Americans would omit the historical experience of racism and the resistance against it which forms part of the Afro-American identity which should not be forgotten if we are making an effort to fully include Afro-Americans into the whole of society. Compare Blum (1994; 1998, p. 56). 
tied to culturally defined groups of individuals, and the civilization in terms of the entire humanity is the intercultural dialogue. The significant feature of the intercultural dialogue is the effort to find certain a transcultural feature in common which might be shared by all cultures and therefore by the entire human civilization. The effort to agree on certain commonly shared fundamental norms makes human rights a significant topic (MARITAIN, 1949). ${ }^{8}$ In this intercultural debate, we often encounter two extreme positions. Given that on one side stand the essentialists and on the other side the relativists, the discussion is analogous to the debate on cultures as mentioned previously.

Leaving aside the intra-cultural discussion on this topic, it is possible to say with respect to the intercultural dialogue that the essentialists as well as the relativists present some convincing arguments, though their fundamental views are questionable (IGNATIEFF, 2001). For essentialists, human rights are not a mere creation of human beings but they have deeper origin. According to the essentialist view, human rights are natural which means that they naturally belong to all human beings or that their origin is divine, etc. All these kinds of views, however diverse in their argumentation, relate to a questionable opinion which states that human rights have an essence which has to be discovered and spread across all cultures. ${ }^{9}$

The relativists justifiably point out the fact that the formulation and promotion of human rights were and are given by their particular selection which was made by one group of individuals or another. This selection is usually promoted as a universal collection of rights and implemented against other norms which are shared by other cultures. The norms of the past were enforced in the similar manner in various colonialist expansions, for example, of which the European colonialism was probably the most famous for as well as its pseudo-universalism of human rights (WALLERSTEIN, 2006). Practices of the contemporary superpowers are, in this respect, followers of this legacy. Various culturally tinged fundamentalisms in various parts of the world are then the other side of the same coin. This pseudo-universalism must be rejected on the same basis as cultural imperialism.

8 The conferences concerning the $60^{\text {th }}$ anniversary of the Universal Declaration of Human Rights took place especially within the framework of various activities of UN under the heading of Dignity and Justice for All of Us: <http://www.ohchr.org/ EN/UDHR/Pages/60UDHRIntroduction.aspx $>$.

9 If this conception of human rights was intra-culturally suitable to a certain community in which it developed and if it was not forced by them upon other communities, the shortfall of such a conception would lie 'only' in the fact that it would not be a case of human rights or the rights belonging to all human beings. 
Nevertheless the objective of essentialists to achieve universal rights is worth following if it was not based on particularism which is not shared by others. In this respect, the relativists fail. It is not possible to deduce from the various present failures as the relativists do attempt, the impossibility of a consensus on universal values and therefore the necessity of the relativism. The possibility of a social construct of universally shared rights which have their bases in various cultures remains here, and likewise the many attempts directed towards its achievement through the intercultural dialogue. The pseudo-universalistic misuse of human rights meanwhile confirms the power of the idea of human rights because it is an example of the fact that various groups of individuals feel it useful to mask their particular interests behind the widely accepted view of human rights. On the other hand the positive contribution of relativism is its acceptance and respect of cultural plurality. But if we do not want to end up in the relativist indifference to genocides, cannibalism, torture and other brutal approaches to human beings, we must admit that recognition of the other persons should contain certain limits which should not be overstepped.

The formulation of commonly shared limits of this kind presupposes mutual understanding between the participants of the dialogue (SCHMIED-KOWARZIK, 2002; HOLENSTEIN, 1999). Every language or languages of individual cultures have their own specific features which are not shared by other cultures. This does not mean that the dispute is absolute and that there is no space for mutual inspiration and overlapping of categories which might be articulated for the purpose of consensus on a specific issue. ${ }^{10}$ These overlapping and universally shared categories may be considered as social constructs which follow on from similar approaches to similar problems which are encountered by various cultures; they could also be cultural universals (WIREDU, 1996) or speech universals (HOLENSTEIN, 1998; HOLESTEIN, 1985), if we use the terms of Kwasi Wiredu, and Elmar Holenstein. Whatever the basis of this is, there are long-term circumstances for socially created universals on a global scale due to the fact that none of the larger cultural circles are isolated and they do influence each other. At least since the $15^{\text {th }}$ century there has been a significant world expansion of the West which was in return influenced in an unequal relationship by cultures which the West encountered. The globalization trends of recent times only encouraged these encounters between cultures. This fact is not an evidence of a kind of shared unity; nevertheless, it is a testimony of at least an awareness of common problems which cannot be ignored. Despite the fact that the

${ }_{10}$ For the conclusions of these thoughts see Taylor (1999). 
list of these problems is by no means identical in all cultures, there are certain overlaps. Although the hierarchy of these issues is not identical between cultures, it is the subject of the discussion itself which can lead to particularly fruitful results. One of these outcomes is a definite level of consensus in regard to designating a group of human rights.

It would be erroneousness to identify the creation of human rights solely within Western civilization and declare the Western authors such as John Locke, John Stuart Mill and others as their creators. The universal characteristics of human rights can be found in various cultures in which the requirements for action and behavior of people were being formed in the course of the historical development of moral, philosophical, religious and other systems of norms. Despite the fact that these rights were gradually formed in a Western context since the $16^{\text {th }}$ century in connection with the American and the French revolutions, the development of a form of human rights has a significantly older tradition amongst many cultures.

Moreover, an important aspect of human rights is not just their formulation but also their active implementation in history. In view of this fact, it is important to realize that equivalents of particular types of human rights were in practice in various non-Western cultures in the past which were often eliminated by Western colonization. The interpretation of the development and implementation of human rights therefore require letting go of illusions about a singular civilization role from one of the cultural circles, namely the West. This should not mean a resignation from articulating human rights also from a Western point of view which should input into the intercultural discussion but not as the main contributor.

The search for some kind of implementation of human rights in the Western culture was often connected with references to the Westphalian era of national states. The national framework of Western thought was the solution for both dominant streams of thinking: the thinking on legislation for the sovereignty of people as well as the thinking on the rights of private individuals concerning despotic rulers and oppressive majorities. These thoughts sometimes turn into disagreements which these two interpretations interlink while connecting the public autonomy of state citizens with the private autonomy of individuals.

Jürgen Habermas explains the relationship between both parts of autonomy within the context of human rights which he conceives as an institutionalization of 'communication conditions' under which we can form a political will (HABERMAS, 1998). The sovereignty of the people gives foundation to democracy and to rights which are interlinked into reciprocal conditioning in the form of private and state autonomies. 
Habermas is also aware of the contentious implementation of worldwide democracy which is apparent from ambivalent comments on this topic in his various texts (HABERMAS, 1998). Multiple notions of democracy which cover areas from formal democracy and democratic populism across to democratic centralism to various versions of Islamic democracy as well as the resistance to forceful and frequently mere rhetorical implementations of democracy beyond Western borders, in the case of the war on Iraq, for example, lead many of its present advocates to cautiousness (COHEN, 2006). The emphasis on intercultural dialogue and tolerance of diverse regimes is presently stressed by various authors, by John Rawls, for example, in his conception of international rights based on the law of nations.

In the effort to arrive at mutual recognition and consensus within the framework of intercultural dialogue, it is necessary to distinguish between at least four types of models of arrangement which are discussed in the dialogue. These models contain various views on cultural, political, social, and economic arrangements.

Firstly, it is possible to try to achieve the least demanding model - modus vivendi, which will ensure a certain consensus in the current power structure. This model is usually part of practical-political thoughts and compromises. Secondly, it may be possible to try to achieve the intercultural model which recognizes the differences of various cultures while searching for the consensus on fundamental human rights as a boundary of acceptable tolerance. This model is more demanding than modus vivendi because its normative conception reaches beyond the current power structure of the participants in the dialogue, while it is less demanding than the collection of all human rights. The achievement of desirable consensus on a collection of all human rights will require overcoming the double meanings of human rights definition. Thirdly, it is possible to recognize other cultures with tolerance although, within the framework of our culture or in a narrow framework of our nation, we can have a more specifically defined idea of human rights which may not be shared by other cultures and nations. In relation to this, it may be said that the welfare state has been forming since the World War II as a consensus of social democrats and Christian democrats in the Western European states and its followers hope that it might be eventually accepted by other cultures. At the same time there are political conceptions within which make claims for their legitimacy. We can advocate significantly more demanding social/socialist and democratic arrangement structure than the one realized up to now in the conception of human rights regime in the European Union or the USA, for example. Fourthly, within the framework of each culture, each nation or each minority unit, there 
are various social groups and individuals that prefer their own so-called comprehensive model which is based on specific philosophical, religious or other views. ${ }^{11}$ They do not try to force this model on other communities and individuals, and they are aware of the fact that it is not shared by all the people. They nevertheless may present this model to others and attempt to justify its persuasiveness.

Therefore, if we try to reach more than the modus vivendi (the first model) we will approach the intercultural model (the second model). Regarding this model, Axel Honneth states that human rights are presently mostly perceived not only as the conditions for communication but as claims that persons recognize each other in order to arrange the necessary social, economic and civic conditions of their respect or dignity (HONNETH, 1995). They are at the same time related to the requirements for the rules of a solidary community of people. The principal definition of these claims for all is a condition for realization of the human existence. People need a guarantee of at least several types of fundamental human rights for the realization of human existence within the framework of the community.

The fundamental value of community which operates on the basis of mutual relationships between members of the community is stressed also by Confucian authors from China and other countries with the Confucian culture, despite the fact that some questions are answered differently. These relationships are various forms of recognition, such as self-esteem, human dignity, equality, and respect for the other, as stated by $\mathrm{C}$. Ihara (IHARA, 2004). The recognition of human dignity and equality of human beings here follows from membership in the community. The rituals $l i$ or relationships in the community serve at the same time the needs of an individual as a foundation of the cultivation of the self as well as the requirements of an arrangement of community (ROSEMONT, 2004).

The Confucian ideal of community together with the ethical notion of social roles and the emphasis on harmonious relationships are principals which, from a Confucian perspective, could stand at the forefront of human rights and which could serve the promotion of humanity. According to D. Wong, both types of traditions: such as the law orientated ones as well as the community orientated ones need such a notion of community which would be able to offer a creative problem solving approach to the relationships of people while ,not losing face' (WONG, 2004). The basis is the inter-subjective notion of the Confucian virtue of zhen. Humanity, which contains a pictogram of relationship of two persons, is a category

11 Rawls distinguishes between comprehensive doctrines and political conceptions which look away from comprehensive doctrines. See Rawls (1993, p. 11 nn). 
of relatedness, of agens societas (KRAL, 2005). It may serve for resolving conflicts in human relationships and so prevent the contentious legal decision making process about correctness at court proceedings. It is possible to speak of community anchoring of rights in this respect.

The emphasis on the community is faced by the strong individualistic tendencies of some Western liberally orientated theories. The Confucians similarly to Western communitarians criticize excessive evaluation of individual rights. Henry Rosemont on the one hand mentions that if the most fundamental human rights are to be considered the individualistically conceived political rights, it would be difficult to anchor the idea of human rights in the Confucian tradition (ROSEMONT, 2004). On the other hand he states that it is possible to incorporate human rights into the Confucian notion of the membership of human beings in the community. ${ }^{12}$

C. Ihara states that, from a Confucian point of view, the individuals' rights are valuable especially at a time when it is necessary to use them in the context of the degradation of communal relationships (IHARA, 2004). The virtues such as relationships based on recognition should play the primary role according to J. Chan while the legislation mechanism should support this role only in the case of it failing to function (CHAN, 1999). This notion is certainly not unusual even to the socially orientated streams of Western theory and praxis. According to various Confucian authors, the main streams of Western thought and praxis may find a consensus with Confucianism on the subject of human rights (BARY and TU, 1998; ANGLE, 2002).

The recognition of women's rights including citizens and social rights, which are discussed more frequently in relation to the Islamic culture, might be promoted with a successful result too, as argued by Adbullah Ahmed An-Na'im. ${ }^{13}$ This might be possible if cultural and religious communities are placed in a more advantageous position rather than if the search of the solution to problems operates only on an abstract level. Norani Othman states that an experience of many active groups of women demonstrates that, in their everyday conflicts, a development was achieved by utilizing specific cultural paradigms (OTHMAN, 1999; AN-NA'IM, 2002; GÖLE, AMMANN, 2006). This does not in the least mean surrendering the secular state. Common approaches shared by Western and non-Western women's movements consist of anchoring in the framework of current social system from which prejudices stem and

12 Now this is realized also by more and more Western authors within the discussion on intercultural dialogue. See, for example, Rawls, (1999, p. $72 \mathrm{nn}$ ).

13 On the interconnectedness of religious, cultural and political discussions in the secular state see An-Na'im (2005). 
against which the fight takes place. The optimal notion of human rights, which is in accordance with Islamic values, is founded in idzhtihad, the critical re-evaluation of Muslim canonical texts which can also include sharia.

The significant measure of human rights lies also in their social and economic dimension. Yash Ghai correctly states that values and attitudes towards rights are primarily conditioned by material relations even despite the fact that there is not an identity of ideology and reality (GHAI, 1999). He points out the effect of globalization on the material situation of people in the example of Asia and in this way also highlights understanding of the rights and their practical implementation. Leslie Sklair analyses two crises in relation to globalization, on the one hand the class polarization and on the other ecological problems of unsustainable development (SKLAIR, 2008). According to Sklair, both crises are connected with the culture and ideology of consumerism which directs the dynamics of global capitalism. Against these crises, he places culture and ideology of human rights in which he sees a potential for the solution of these crises. Human rights are conceived as rights which also have a social and economic dimension from which democracy benefits.

A similar topic from a different perspective is formulated by Jeffrey Flynn who also talks about the material conditions of intercultural dialogue. He argues that it is necessary to overcome the usual focus of intercultural dialogue. He concerns with the wider social and economic context in which intercultural dialogue takes place on the one hand, and on the other hand, with duties, especially with social and economic human rights (FLYNN, 2008). Intercultural dialogue might arise with more difficulties in the situation of the extreme poverty which rules many people especially in developing countries. Only the abolishment of poverty will enable legitimate formation of institutions which could operate in the cosmopolitan environment. This approach requires focusing not just on moral-legal discourse but more prominently on the ethicalpolitical discourse than has been the case up until now, which means a discourse based on a community relationships framework. This emphasis also means a more in depth interest in the practical implementation of the norms.

The responsibility for the promotion of human rights is presently carried by individual states that are, in the contemporary era of globalization, increasingly less able to guarantee the promotion and implementation of human rights because of a weakening influence of the states towards the strong global economic actors, mainly transnational corporations. It is therefore necessary to research and promote human rights in the present post-Westphalian era with the aid of intercultural dialogue at 
a local community level across to national and international levels of communities and finally at a global level.

\section{Conclusion: "Magna Charta" for the whole of humanity}

The proposed view so far necessitates raising the more empirical question about the formation of a legal document such as the 'Magna Charta for the whole of humanity'. Within the framework of current international law, the first one of these legal documents is the well known The Universal Declaration of Human Rights.

The lesson taken from the World War Two led to the creation of the UN and the establishment of the UN Commission for Human Rights in 1946, which was already from the outset concerned with a proposal for the universal declaration of human rights. Initially, the representatives of 18 states participated, while a group of 8 individuals from Australia, Chile, China, France, Lebanon, USSR, Great Britain, and USA participated on the formulation of the Declaration. The Secretariat of UN subsequently prepared the proposal on the basis of these formulations which were the foundation for further discussions and proposals for changes from other Member states.

The declaration was accepted in 1948 at the UN General Assembly in the presence of 58 Member states from many cultural circles. 48 of them voted for its benefit, 8 abstained, and the representatives of 2 states were not present at the vote. ${ }^{14}$ It is therefore possible to say that although the original proposal was created by the group of individuals which was not sufficiently representatively composed from the representatives of many nations and various cultures of the whole world, the following discussions and approval of the document were already achieved by a relatively comprehensive even if not exhaustive representation.

The text of the Declaration is a result of an attempt to formulate binding norms which could be shared across individual nations and cultures. Due to the fact that representatives of various cultural circles participated on the formulation of this Declaration with an endeavor to find common norms, it can be considered almost as a transcultural result of an intercultural dialogue. It certainly is not a perfect result which would fulfill all requirements placed on the intercultural representation and on transcultural consensus. Nonetheless, it is possible to talk about one of the first few articulations of global standards. In the age of planetary, military and other types of aggressive interactions, such an intercultural vision for transculturally shared values is an act of considerable significance. Transcultural models of human rights provide a common normative

14 Declaration was approved on $10^{\text {th }}$ December 1948 in Palais de Chaillot in Paris. General Assembly Resolution 217 A (III), 1948. 
foundation which should be the starting point in supporting the abolition of various military and other types of conflicts.

Although the Declaration is not legally binding, it became the basis for the creation of a number of documents which are legally binding. Let's mention at least the International Covenant on Economic, Social and Cultural Rights and the International Covenant on Civil and Political Rights. ${ }^{15}$ Both Covenants were approved by many states in the UN General Assembly, and they were both more or less equally ratified into the present times by the majority of the states. ${ }^{16}$ Other legal documents further specify and supplement these Covenants in relation to various social, economic, cultural, political, citizens, environmental and other rights (SKLAIR, 2008).

Various rights must be sufficiently defined against each other. In this respect, the UN promotes three fundamental characteristics of human rights: universality, indivisibility, interdependence. I would like to stress especially the importance of the fact that the economic, cultural, civil, political, and social rights, if presented in alphabetical order, are mutually conditioned and supported. However, it does not yet guarantee the consensus on exactly what rights to promote and what kind of relationship should exist between these rights. A typical example is the conflict between social and political rights or the conflict between individual rights and the rights interconnected with living in community. This conflict is apparent in discussions between the North and South, between the West and East, or between the individual states.

It is essential to realize that ratified human rights in international documents are so far a claim which has not yet quite been achieved. That is exactly why we talk about fundamental human rights which should be fulfilled and achieved first. At the same time it is necessary not to give up on the discussion about the more extensive collection of human rights which has already been defined in international documents. The accomplishment of human rights requires the support of a collection of fundamental human rights which can receive stronger support and thus

15 Covenants were approved in 1966 after almost 20 years of the preparatory process within the framework of UN. They came into force 10 years later in 1976, after necessary ratification process. The International Covenant on Economic, Social and Cultural Rights (1966, 1976); The International Covenant on Citizen and Political Rights (1966, 1976).

16 The number of states that ratified the International Covenant on Economic, Social and Cultural Rights was 158 by $18^{\text {th }}$ April 2008, and the number of states that ratified the International Covenant on Citizen and Political Rights was 161. See: Ratifications and Reservations: http://www2.ohchr.org/english/bodies/ratification/4.htm. In regard of the economic, social and cultural rights see: Ratifications and Reservations: http://www2.ohchr.org/english/bodies/ratification/3.htm. 
wider implementation. It will be easier to move from the fundamental human rights to the wider collection of human rights and possibly to their redefined and gradually specified form. This is nonetheless a complex matter and challenging topic for the intercultural discussion.

In the end of this article, I would like to stress the requirement that each side of the dialogue should be recognized by getting social and other conditions for offering their own proposal in the process of intercultural forming of transcultural norms. The proposals should then be discussed with the aim to approve a common proposal. It would not be acceptable to create quasi-transcultural human rights as an offshoot of Western national rights. Thus, it is important that we are not only open to the global redefinition of our viewpoints and to proposals of other cultures but also that we get involved in the argumentation on various levels with the appropriate models of arrangement and from various perspectives of the dialogue, as I discussed in this article.

\section{References}

ADORNO, T. W.; HORKHEIMER, M. Dialektik der Aufklärung. Frankfurt, M.: Fischer, 1988. (1st ed. 1944).

ANGLE, S. C. Human Rights and Chinese Thought: A Cross-Cultural Inquiry. Cambridge: Cambridge University Press, 2002.

AN-NA'IM, A. A. (Ed.). Human Rights in Cross-Cultural Perspectives: A Quest for Consensus. Philadelphia: University of Pennsylvania Press, 1992.

AN-NA'IM, A. A. Cultural Transformation and Human Rights in Africa. London: Zed Books, 2002.

AN-NA'IM, A. A. The Interdependence of Religion, Secularism, and Human Rights. Symposium Talking Peace with Gods, Part 2. Common Knowledge, 11, 1 (2005), p. 56-80.

ARNASON, J. P. Civilizations in Dispute. Historical Questions and Theoretical Traditions. Leiden, Boston: Brill, 2003.

BARY, T. de; TU, W. Confucianism and Human Rights. New York: Columbia University Press, 1998.

BENJAMIN, N. Civilizational Complexes and Intercivilizational Encounters. Sociological Analysis, 34, 2 (1973), p. 79-105.

BLUM, L. A. Multiculturalism, Racial Justice, and Community: Reflections on Charles Taylor's "Politics of Recognition". In: FOSTER, L.; HERZOG, P. (Eds.). Defending Diversity: Contemporary Philosophical Perspectives on Pluralism and Multiculturalism. Amherst: University of Massachusetts Press, 1994, p. 175-205.

BLUM, L. A. Recognition, Value, and Equality. Constellations, 1 (1998), p. 53, $57 \mathrm{nn}$.

CHAN, J. A Confucian Perspective on Human Rights for Contemporary China. In: BAUER, J. R.; BELL, D. A. (Eds.). The East Asian Challenge for Human Rights. Cambridge, Cambridge University Press, 1999, p. 212-237. 
COHEN, Joshua. Is there a Human Right to Democracy? In: SYPNOWICH, Ch. (Ed.). Egalitarian Conscience: Essays in Honour of G. A. Cohen. Oxford: Oxford University Press, 2006, p. 226-248.

DIAMOND, J. Guns, Germs, and Steel: The Fates of Human Societies. W. W. Norton, 1997.

EISENSTADT, S. N. (Ed.). Multiple Modernities. New Brunswick: Transactions Publishers, 2002.

ELIAS, N. The Civilizing Process: Sociogenetic and Psychogenetic Investigations. London: Wiley-Blackwell, 2000.

FLYNN, J. Human Rights, Transnational Solidarity, and Duties to the Global Poor. In: HRUBEC, M. (Ed.). Interkulturni dialog o lidskych pravech. Zapadni, islamske a konfucianske perspektivy (An Intercultural Dialogue on Human Rights. The Western, Islamic, and Confucian Perspectives). Prague: Filosofia, 2008.

FRASER, N.; HONNETH, A. Redistribution or Recognition? London and New York: Verso, 2003.

GHAI, Y. Rights, Social Justice, and Globalization in East Asia. In: BAUER, J. R.; BELL, D. A. (Eds.). The East Asian Challenge for Human Rights. Cambridge: Cambridge University Press, 1999, p. 241-263.

GÖLE, N.; AMMANN, L. (Eds.). Islam in Public. Istanbul: Istanbul Bilgi University Press, 2006.

HABERMAS, J. Theorie des kommunikativen Handelns. Frankfurt, M.: Suhrkamp, 1981.

HABERMAS, J. Zur Legitimation durch Menschenrechte. In: HABERMAS, J. Die postnationale Konstellation. Politische Essays. Frankfurt, M.: Suhrkamp, 1998, p. 170-192.

HABERMAS, J. Die postnationale Konstellation. Frankfurt, M.: Suhrkamp, 1998.

HARRIS, J. The Dialectics of Globalization: Economic and Political Conflict in a Transnational World. Cambridge: Cambridge Scholars Press, 2008.

HOLESTEIN, E. Sprachliche Universalien: Eine Untersuchung zur Natur des menschlichen Geistes. BOCHUM: Brockmeyer, 1985.

HOLENSTEIN, E. Kulturphilosophische Perspektiven. Frankfurt, M.: Suhrkamp, 1998.

HOLENSTEIN, E. Menschliches Selbstverständnis. Frankfurt, M.: Suhrkamp, 1999.

HONNETH, A. Kampf um Anerkennung. Frankfurt, M.: Suhrkamp, 1992. (In English: The Struggle for Recognition. Cambridge: Polity Press, 1995).

HUNTINGTON, S. The Clash of Civilizations and the Remaking of World Order. New York, Simon \& Schuster, 1996.

IGNATIEFF, M. Human Rights as Politics and Idolatry. A. Gutmann (Ed.). Princeton, Oxford, Princeton University Press, 2001.

IHARA, C. K. Are Individual Rights Necessary? A Confucian Perspective. In: SHUN, K.-L.; WONG, D. B. (Eds.). Confucian Ethics. A Comparative Study of Self, Autonomy, and Community. Cambridge: Cambridge University Press, 2004, p. 11-30.

INGRAM, J. Comment on Lawrence Blum. Constellations, 1, 5 (1998), p. 69-73. 
KÖGLER, H.-H. Recognition and Difference. The Power of Perspectives in Interpretative Dialogue. Social Identities, 11, 3 (2005).

KRAL, O. Cinska filosofie. Pohled z dejin. Lasenice: Maxima, 2005.

KROEBER, A. L.; KLUCKHOHN, C. Culture: A Critical Review of Concepts and Definitions. New York: Vintage Books, Random House, 1963.

MARITAIN, J. Human Rights: Comments and Interpretations. New York: Columbia University Press, UNESCO, 1949.

ONUMA, Y. Towars an Intercivilizational Approach to Human Rights. In: BAUER, J. R.; BELL, D. A. (Eds.). The East Asian Challenge for Human Rights. Cambridge, Cambridge University Press, 1999, p. 103-123.

OTHMAN, N. Grounding Human Rights Arguments in Non-Western Culture: Shari'a and the Citizenship Rights of Women in a Modern Islamic State. In: BAUER, J. R.; BELL, D. A. (Eds.). The East Asian Challenge for Human Rights. Cambridge: Cambridge University Press, 1999, p. 169-192.

RAWLS, J. Political Liberalism. New York, Columbia University Press, 1993.

RAWLS, J. The Law of Peoples with "The Idea of Public Reason Revisited". Cambridge, MA: Harvard University Press, 1999.

ROBINSON, W. A Theory of Global Capitalism: Production, Class, and State in a Transnational World. Baltimore, Maryland, The Johns Hopkins University Press, 2004.

ROSEMONT Jr., H. Whose Democracy? Which Rights? A Confucian Critique of Modern Western Liberalism. In: SHUN, K.-L.; WONG, D. B. (Eds.). Confucian Ethics. A Comparative Study of Self, Autonomy, and Community. Cambridge, Cambridge University Press, 2004, p. 49-71.

SAID, E. W. Culture and Imperialism. New York, Vintage, 1994.

SAMSON, C.; SMITH, N. (Eds.). The Social Construction of Social Policies. Methodologies, Racism, Citizenship and the Environment. New York: St. Martin, 1996.

SCHMIED-KOWARZIK, W. (Hg.). Verstehen und Verständigung. Ethnologie-Xenologie - Interkulturelle Philosophie. Würzburg: Königshausen und Neumann, 2002.

SENGHAAS, D. (1998). Zivilisierung wider Willen. Der Konflikt der Kulturen mit sich selbst. Frankfurt, M.: Suhrkamp.

SENGHAAS, D. On Perpetual Peace: A Timely Assessment. New York: Berghahn Books, 2007.

SKLAIR, L. Globalizace lidskych prav (The Globalization of Human Rights). In: HRUBEC, M. (Ed.). Interkulturni dialog o lidskych pravech. Zapadni, islamske a konfucianske perspektivy (An Intercultural Dialogue on Human Rights. The Western, Islamic, and Confucian Perspectives). Prague: Filosofia, 2008, p. 49-81.

SPENGLER, O. Der Untergang des Abendlandes. Umrisse einer Morphologie der Weltgeschichte. München, Taschenbuch, 2006. (1st ed. 1919-1922).

TAYLOR, C. The Ethics of Authenticity. Cambridge, MA, and London, 1992.

TAYLOR, C. Multiculturalism. The Examining the Politics of Recognition. A. Gutmann. (Ed.). Princeton, Princeton University Press, 1994.

TAYLOR, C. Conditions of an Unforced Consensus on Human Rights. In: BAUER, J.; BELL, D. A. (Eds.). The East Asian Challenge for Human Rights. Cambridge, Cambridge University Press, 1999, p. 124-144. 
TEHRANIAN, M. Rethinking Civilization: Resolving Conflict in the Human Family. London-New York, Routledge, 2007.

TÖNNIES, A. Gemeinschaft und Gesellschaft. Grundbegriffe der reinen Soziologie. Darmstadt, Wissenschaftliche Buchgesellschaft, 2005. (1st ed. 1887).

TOYNBEE, A. J. A Study of History. Oxford, Oxford University Press, 1961. (1st ed. 1934).

WALLERSTEIN, I. European universalism. New York, New Press, 2006.

WIREDU, K. Cultural Universals and Particulars: An African Perspective. Bloomington, Indiana University Press, 1996.

WONG, D. B. Rights and Community in Confucianism. In: SHUN, K.-L.; WONG, D. B. (Eds.). Confucian Ethics. A Comparative Study of Self, Autonomy, and Community. Cambridge, Cambridge University Press, 2004, p. 31-48. 